\title{
Boekbesprekings/Hook Reviews
}

\section{STORMVÖ̈L VAN DIE NOORDE - Step- hanus Schoeman vir Transvaal. Geskryf deur O. J. O. Ferreira. Uitgegee deur Makro-Boeke, Pretoria, 1978.}

Die boek handel oor die lewe van Stephanus Schoeman, die een hoofkarakter in die struwelingsjare van die ou Suid-Afrikaanse Republiek. $\mathrm{Hy}$ was agtereenvolgens kommandant van Potchefstroom, kommandant-generaal van Soutpansberg, kommandant-generaal van die SuidAfrikaanse Republiek, waarnemende en ook selfaangestelde, president van die SuidAfrikaanse Republiek, bevelvoerder van die Pretoria Rifle Corps en diplomatieke agent in Soutpansberg. Die navorsing oorspan dus sowat 80 jaar van Suid-Afrikaanse geskiedenis, met die klem op die staatkundige gebeure in die Suid-Afrikaanse Republiek.

Die skrywer, dr Ferreira, het intens navorsing gedoen en geen steen onaangeroerd gelaat in sy poging om alle kante van Schoeman se lewe te belig nie. 'n Biografie bly natuurlik 'n uiters moeilike onderwerp vir 'n doktorale studie. Die standaard wat prof Thom met sy werk oor Gerrit Maritz, gestel het kan moeilik oortref word. Tog slaag die biograaf van Schoeman daarin om die leser emosioneel te betrek. Soms wil die leser verergd uitroep en sê dat Schoeman ' $n$ korrelkop, 'n dwarstrekker is, maar dan temper die skrywer weer hierdie gevoel. Veral in die laaste hoofstuk slaag die skrywer daarin om Schoeman te laat leef.

Uit 'n militêr-historiese oogpunt het die hoofstuk oor die Pretoria Rifle Corps beslis opgeval. Schoeman word, nadat hy homself as waarnemende staatspresident aangestel het, voëlvry verklaar. Dit word op 12 Junie 1865 opgehef. Schoeman was nou sonder enige amptelike betrekking. Dit is toe dat hy besluit het om 'n Vrywilligerkorps te stig. Die naam klink Engels, maar, soos die skrywer aandui, kom die 'Rifle' van die nuwe Westley Richardsdoppieagterlaaier wat in dié tyd in Transvaal in gebruik geneem is. Schoeman word die bevelvoerder, met die rang van kaptein en die Staatspresident word die Ere-kolonel. Sover my kennis strek, was dit die eerste Vrywilligerkorps in Transvaal en ook gans vreemd binne die Kommando-opset van die Transvalers.

Stormvoël van die Noorde is 'n puik historiese werk wat slegs deur fynproewers en ernstige historici gewaardeer sal kan word. 'n Boek wat met trots sy plek in die klein groepie Afrikaanse historiese werke sal kan volstaan.

Stormvoël van die Noorde is gedruk en gebind deur Promedia Publikasies en uitgegee deur Makro-Boeke, Pretoria, as die eerste in 'n reeks bekend as Historica. Opvallend - en verblydend - dat daar nog uitgewers is wat bereid is om goeie boeke te bemark, ongeag die geringe aantal lesers van histories-wetenskaplike werke.

Kapt A. E. van Jaarsveldt

\section{MEREDITH, Martin: \\ The past is another country, Rhodesia 1890-1979 London, Deutsch, 1979}

Hierdie boek voorsien in ' $n$ leemte betreffende die politieke gebeure in Rhodesië vanaf die hysing van die Union Jack aan 'n krom msasapaal naby Harare op 13 September 1890 tydens die besetting van Mashonaland in die naam van die Britse koningin tot die oggend van 1 Junie 1979 toe Biskop Abel Muzorewa sy eerste werksdag as Eerste Minister van Rhodesië begin het.

Die blanke het van meet af ' $n$ meerderwaardigheid openbaar teenoor die kultuur van die Swartes en dit is gereflekteer in die beperkende wetgewing en afskeping van die sosiale dienste. Die outeur toon egter dat Swart Nasionalisme ten spyte van hierdie wetlike beperkings en sosiale diskriminasie nogtans dinamies ontwikkel het gedurende die tydperk wat deur hierdie boek gedek word.

Aan die anderkant word aangetoon die aanvanklike mislukte pogings van regeringskant om eers die Swart Nasionalisme te onderdruk, daarna veral gedurende die Federasie-tydperk om hierdie ontwikkelende nasionalisme te paai en 
uiteindelik die uitbarsting van geweld vanaf die kant van die Swartes wat nie meer die minderheidsaandeel in die regering kon aanvaar nie.

Hierdie politieke oorsig ontvou soos 'n drama op die verhoog van Afrika met lan Smith, Muzorewa, Mugabe, Nkomo, Sithole as die hoofkarakters en met die verskillende gesante van die Britse regering en die Amerikaanse regering wat van tyd tot tyd op die toneel verskyn om Rhodesië van onafhanklikheid te weerhou indien daar nie 'n Swart meerderheidsregering tot stand kom nie en om dan wanneer daar wel aan hierdie vereiste voldoen word weer eens erkenning daarvan te weerhou.

Die ideaal wat Smith vir Rhodesië voorhou en waaraan hy te midde van al die storm en drang van die Swart Nasionalisme asook die buitelandse teenkanting steeds bly vashou kom duidelik na vore.

Die toedrag van sake word verder bemoeilik deur die ondersoek van die Pearce-Kommissie gedurende 1972. Die bevindinge en uitsprake van hierdie kommissie dien as katalisator om die vlamme van Swart Nasionalisme opnuut hoog te laat opvlam en die greep wat Smith die vorige sewe jaar daarop uitgeoefen het, merkbaar te laat verslap.

Voorts bespreek die outeur die uitbreek en die verloop van die guerrilla-oorlog wat vanuit
Rhodesië se buurstate asook binnelands geloods word en die gepaardgaande verdeling van lojaliteit teenoor die verskillende Swart leiers wat mettertyd na vore getree het.

Suid-Afrika se rol gedurende die detenteperiode word baie prominent beskryf aangesien die Suid-Afrikaanse regering dikwels sy invloed baie subtiel moes uitoefen omdat sy posisie baie delikaat en problematies was. Volgens die outeur het Vorster probeer om tot ' $n$ begrip met Afrika-lande in sleutelposisies te kom en het hy ook gepoog om Smith by sy detente-pogings te betrek.

Verskeie skikkingspogings soos dié deur Kissinger, die Geneefse Konferensie en die Anglo-Amerikaanse poging deur Owen en Young word ook bespreek.

Met sy spesifieke kombinasie van buitelandse probleme asook die faktore wat binnelands teen hom gewerk het, kon Smith uiteindelik nie anders as om op 3 Maart 1979 Blanke heerskappy finaal af te gee nie.

Die stof vir hierdie boek is oor 'n tydperk van 'n hele paar jaar deur die outeur versamel toe hy as buitelandse korrespondent (verslaggewer) in Suider Afrika aktief was, asook tydens besoeke aan Londen en Washington.

A. O. Claase 